\title{
Szisztémás gyógyszerek szemészeti mellékhatásai
}

\author{
Czakó Cecília dr. - Sándor Gábor dr. - Horváth Hajnalka dr. \\ Szepessy Zsuzsanna dr. - Nagy Zoltán Zsolt dr. - Kovács Illés dr.
}

Semmelweis Egyetem, Általános Orvostudományi Kar, Szemészeti Klinika, Budapest

\begin{abstract}
A különböző szerveket érintő betegségek gyógyításában szisztémásan alkalmazott gyógyszerek szemészeti mellékhatásai lehetnek tünetmentes elváltozások, azonban látást veszélyeztető kórképek is, mint a toxikus retinopathia vagy az opticus neuropathia. A szemészeti szürővizsgálatok során a mellékhatások korai felismerésével a további progresszió és a maradandó látáskárosodás az esetek többségében megelőzhető. Összefoglaló közleményünkben a klinikai gyakorlatban széles körben használt gyógyszerek leggyakoribb és legjelentősebb szemészeti mellékhatásait ismertetjük. Célunk a gyógyszereket felíró orvosok tájékoztatása a terápia lehetséges szemészeti szövődményeiról, a szemészeti vizsgálatok fontosságáról és rendszerességéről.

Orv Hetil. 2020; 161(23): 951-961.
\end{abstract}

Kulcsszavak: szisztémás gyógyszerek, szemészeti mellékhatások, toxikus retinopathia, opticus neuropathia, intraoperatív 'floppy' iris szindróma

\section{Adverse ocular effects to systemic drug therapy}

Systemic medications of various diseases can have adverse effects on the eye that range from asymptomatic lesions to potentially blinding complications such as toxic retinopathy and optic neuropathy. In the course of ophthalmological screening, with the early detection of toxic effects, the majority of drug-induced eye disorders can be prevented and even be reversed. Our review focuses on major drugs with common and significant ocular side effects. Physicians prescribing medications need to be keenly aware of ocular toxicity risks and the importance of regular screening.

Keywords: systemic medications, ocular side effects, toxic retinopathy, optic neuropathy, intraoperative floppy iris syndrome

Czakó C, Sándor G, Horváth H, Szepessy Zs, Nagy ZZs, Kovács I. [Adverse ocular effects to systemic drug therapy]. Orv Hetil. 2020; 161(23): 951-961.

(Beérkezett: 2020. január 6.; elfogadva: 2020. január 30.)

\section{Rövidítések}

$\mathrm{AAO}=($ American Ophthalmic Association $)$ Amerikai Szemészeti Kollégium; A-EION = arteritises elülső ischaemiás opticus neuropathia; $\mathrm{BPH}=$ (benign prostatic hyperplasia) benignus prosztatamegnagyobbodás; CSC = centrális serosus chorioretinopathia; ERG = elektroretinográfia; IFIS = (intraoperative floppy iris syndrome) mütét közben lebegő iris szindróma; IFN = interferon; LUTS = (lower urinary tract syndrome) vizeletürítési zavarok; $\mathrm{MEK}=$ mitogénaktivált proteinkináz; MEKAR = MEK-inhibitor-asszociált retinopathia; NA-EION = nonarteritises elülső ischaemiás opticus neuropathia; $\mathrm{OCT}=$ (optical coherence tomography) optikaikoherencia-tomográfia; $\mathrm{PDE}=$ foszfodiészteráz; $\mathrm{PTC}=$ pseudotumor cerebri; RA = rheumatoid arthritis; SLE $=$ (systemic lupus erythematosus) szisztémás lupus erythematosus; $\mathrm{SRF}=($ subretinal fluid $)$ subretinalis folyadékgyülem; SSRI = (selective serotonin reuptake inhibitor) szelektív szerotoninvisszavétel-gátló; $\mathrm{TCA}=$ (tricyclic antidepressant $)$ triciklusos antidepresszáns; UV = (ultraviolet) ultraibolya; VEGF = (vascular endothelial growth factor) vascularis endothelialis növekedési faktor; VEP = (visual evoked potential) látókérgi kiváltott válasz

Számos, széles körben alkalmazott szisztémás terápia jár szemészeti mellékhatások kialakulásával, melyek lehetnek enyhe, tünetmentes elváltozások, de látást veszélyeztető, maradandó károsodással is járhatnak. A szemgolyónak a szervezethez viszonyított kis tömege és bőséges vérellátása miatt a szisztémás gyógyszerek okozta szemészeti szövődmények kialakulása nem ritka jelenség. 
A gyógyszer molekulái a szisztémás keringésből a szemgolyót az uvealis és a retinalis vérkeringésen keresztül érik el. Az avascularis képletekhez - mint a cornea és a szemlencse - a molekulák diffúzió útján jutnak el. Amennyiben a gyógyszer lerakódik, és nem eliminálódik a szemből, a toxicitás kockázata megnő. A gyógyszerek látásra kifejtett hatása változatos lehet, az átmeneti látásromlástól a látás végleges elvesztéséig. A károsodás lokalizációjától függően a látáspanaszok megnyilvánulhatnak a fényforrások körüli színes udvar (halo) látásában, káprázásos panaszokban, akkomodációs zavarokban, homályos látásban, színlátászavarokban és látótérkiesésekben.

A szemészeti vizsgálat során a részletes anamnézisfelvételhez hozzátartozik a beteg gyógyszereinek kikérdezése, a terápia dózisa és a gyógyszerszedés időtartama fontos információ lehet. Olyan szemészeti tünetek és panaszok esetén, amikor az elváltozásnak nincs egyértelmú oka, a szemorvosnak gondolnia kell a szisztémásan szedett gyógyszerek toxikus hatásainak lehetőségére is. A különböző gyógyszerek szedése esetén javasolt szemészeti kontrollvizsgálatok betartása alapvető jelentőségü, mert az esetek többségében a toxicitás korai jeleinek észlelésekor a terápia felfüggesztésével az állapot visszafordítható, és a látás megőrizhető.

Összefoglaló közleményünk célja, hogy a szisztémás gyógyszerek leggyakrabban előforduló és legjelentősebb szemészeti mellékhatásait megismertessük a társszakmák orvosaival, valamint felhívjuk a figyelmet a gyógyszerek szedése esetén a szemészeti szűrés fontosságára.

\section{Amiodaron - Cornea verticillata és opticus neuropathia}

A szívritmuszavarok terápiájaként használt amiodaron a szem különböző részeiben okozhat elváltozást. A leggyakoribb ezek közül a corneadepozitumok megjelenése, más néven amiodaronkeratopathia, vortex keratopathia vagy cornea verticillata. Klinikailag barnás vagy szürkés, a cornea epitheliumában megjelenő depozitumok jellemzik a középső és az alsó harmad határán (1. ábra), amelyek megjelenése függ a gyógyszer szedésének dózisától és a gyógyszerszedés időtartamától is. Az előfordulás nagyon gyakori, az amiodaronszedők 69-100\%-ában megfigyelhető. Kialakulása három stádiumban, minimum 1 hónapnyi gyógyszerszedést követően történik. Az első szakaszban, napi 200-400 mg amiodaron szedése mellett először egy horizontális vonal jelenik meg a corneán, mely magasabb dózisnál (400-1400 mg) macskabajusz-, majd örvényszerű rajzolatot vesz fel. A depozitumok a leggyakrabban kétoldaliak, és az esetek többségében nem okoznak látásromlást. Ugyanakkor a fényforrások körül megjelenő színes karika (halo) fényjelensége, fényérzékenység (photophobia) előfordulhat. Az amiodaron szedésének abbahagyását követően az elváltozás teljes visszafejlődése 3-20 hónapot vehet igénybe [1]. Az amiodaronkeratopathia a gyógyszer abbahagyá-

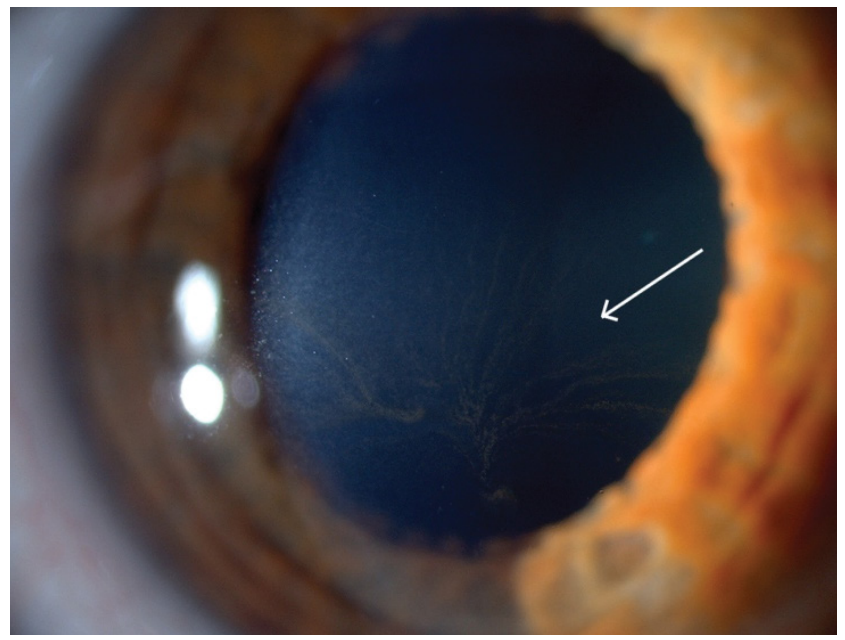

1. ábra

Amiodaronszedés kapcsán megjelenő cornea verticillata típusos klinikai képe. A cornea alsó és középső harmadának határán kialakuló, örvényszerú rajzolatot mutató depozitumok (nyíl) látáspanaszokat nem okoznak

sának nem indikációja a ritka és látást nem veszélyeztető látáspanaszok miatt.

$\mathrm{Az}$ amiodaron okozta opticus neuropathia jóval ritkábban, irodalmi adatok szerint az esetek 0,36-2\%-ában fordul elő [2], azonban súlyos és maradandó látásromlással járhat. A legtöbb esetben a gyógyszer szedésének kezdetét követő első évben következik be. Klinikai lefolyására fokozatosan megjelenő, lassú progressziót mutató neuropathia jellemző, mely végső esetben papillaoedemához vezethet. Leggyakoribb tünetei a látóélesség-csökkenés, a színlátászavar (dyschromatopsia) és a látótérkiesés. Az elülső ischaemiás opticus neuropathiától való elkülönítése nehézséget jelenthet, segíthet azonban a lappangó kezdet, a kétoldali érintettség és a papillaoedema elhúzódó visszafejlődése. Időben történő felismerése fontos, mivel a gyógyszer hosszú felezési idővel rendelkezik, így az amiodaron abbahagyását követően is további, súlyos károsodást okozhat. Diagnózisa az opticus neuropathia egyéb lehetséges okainak kizárásával történik. Amennyiben a gyanú felmerül, a kardiológussal történő konzultációt követően a gyógyszer dózisának csökkentése vagy más gyógyszerre történő váltás javasolt. Az amiodaronnak a látást veszélyeztető mellékhatásai miatt a gyógyszer szedése előtt ajánlott egy kiindulási szemészeti vizsgálat, majd a szedés alatt az első évben félévente, ezt követően évente történő kontrollvizsgálat [3]. A szűrővizsgálatok során a látóélesség-felvétel és a látótérvizsgálat mellett színlátástesztek elvégzése is javasolt, mivel opticus neuropathia esetén a dyschromatopsia jelentősebb mértékű lehet, mint a látóélesség-csökkenés.

\section{Kortikoszteroidok - Szteroidglaucoma és hátsó kérgi cataracta}

A szteroidok lokális és szisztémás formában történő alkalmazása egyaránt okozhat szemészeti mellékhatáso- 


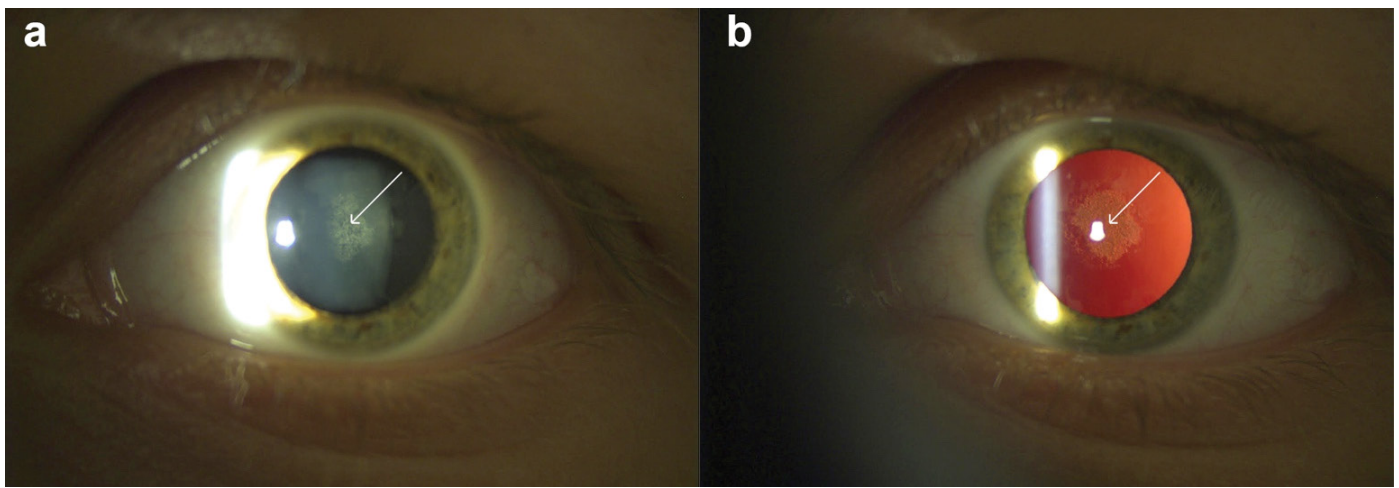

kat. A szisztémásan adott kortikoszteroidok indikációs területe az autoimmun betegségeken túl olyan látást veszélyeztető szemészeti kórképek, mint az arteritises eredetű elülső ischaemiás opticus neuropathia és a hátsó uveitisek. A szteroidok fó szemészeti mellékhatása a szteroid indukálta glaucoma és a hátsó kérgi cataracta kialakulása, ezenkívül elhúzódó sebgyógyulást és fertőzésekre való fokozott hajlamot okozhat. A szteroidterápia hatására a trabecularis hálózati extracelluláris mátrixproteinek szintézise fokozódik, a csarnokvíz elvezetése akadályozott lesz, és az intraocularis szemnyomás megemelkedhet. Szteroidreszponder betegeknél a szemnyomás a szteroidszemcsepp-használat kezdete utáni első pár hétben emelkedik meg, és a terápia abbahagyását követően 1-4 héten belül rendeződik. A tartósan fennálló magasabb szemnyomás glaucomás látóidegfő-károsodást és következményes látótérkiesést okoz. A szteroid indukálta glaucoma kialakulása a szteroidhasználat időtartamán kívül függ a beteg glaucomára hajlamosító rizikófaktoraitól is. Habár a glaucoma egy potenciálisan vakságot okozó kórkép, korai felismeréssel és a megfelelő szemnyomáscsökkentő terápia időben történő elkezdésével az irreverzibilis opticus neuropathia kialakulása megelőzhető. A szisztémás úton adott szteroidok ritkán okoznak szemnyomás-emelkedést. Amennyiben előfordul, a szemnyomás-emelkedés mér- téke nincs összefüggésben a szteroid dózisával és a terápia időtartamával [4].

A szteroidterápia további mellékhatása a hátsó kérgi cataracta kialakulása, mely jellemzően a hátsó kéregben, közvetlenül a tok alatt a centrumban elhelyezkedő szemcsézett homályként jelenik meg (2. ábra). Centrális lokalizációja miatt szúk pupilla mellett kifejezettebbek a látáspanaszok. A kialakulás patomechanizmusa nem teljesen tisztázott, a legelfogadottabb elmélet szerint a kortikoszteroidok gátolják a lencse ekvátorán lévő epithelsejtek lencserostokká történő differenciálódását, és a lencse hátsó pólusára vándorolnak. A cataracta megjelenése gyakoribb lokális szteroidterápia mellett, azonban a tartósan, több mint két éven keresztül, napi 25-80 mg dózisú, szisztémásan szedett szteroid hatására is kialakulhat [5]. Randomizált kontrollált tanulmányok eredményei alapján előfordulási valószínúsége szájon át szedett kortikoszteroid esetén 6,4-38,7\% [6]. A cataracta kialakulásának veszélye lokális szteroidterápia alkalmazásakor gyermekek esetén magasabb [7]. Habár a cataracta okozta tünetek a szürkehályog-mütét elvégzésével viszszafordíthatók, nem szabad elfeledkeznünk a mütét kapcsán esetlegesen előforduló szövődményekrôl sem.

A centrális serosus chorioretinopathia (CSC) a retina neuroszenzoros rétege és pigmenthámja között létrejövő folyadékgyülem (3. ábra). Kialakulásának egyik leg-

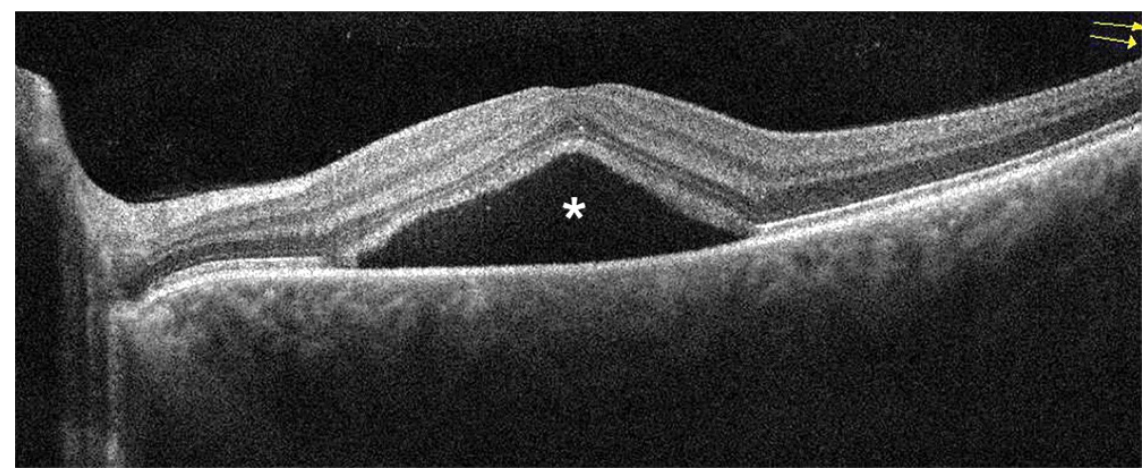

3. ábra $\quad$ Centrális serosus chorioretinopathia OCT-felvétele. A neuroszenzoros retina alatt kialakuló subretinalis folyadékgyülem (csillag) a centrális látás csökkenését és hyperopiás shiftet okoz

OCT $=$ optikaikoherencia-tomográfia 
fontosabb rizikófaktora a külső kortikoszteroidbevitel. A szájon át történő és intravénás alkalmazáson kívül inhalációs, intranasalis, intraarticularis és transdermalis bevitelt követően is közöltek eseteket [8]. A szteroidok kiváltotta CSC-re jellemző a kétoldali és atípusos megjelenés, mely a kezelést követően 6 nappal és akár 10 évvel is előfordulhat. A maculatájon kialakuló subretinalis folyadékgyülem (SRF) jellegzetes klinikai tünetei a centrális látás csökkenése és a fénytörésnek a távollátás (hypermetropia) irányába történő eltolódása (hyperopiás shift); esetenként a betegek a vonalak torzulására (metamorphopsia) és a tárgyak valóságosnál kisebb méretú látására (micropsia) panaszkodnak. A szteroidterápia dózisa és időtartama, valamint a CSC megjelenése között nem találtak összefüggést, már alacsony dózis mellett is számoltak be esetekről [9].

\section{Klorokin, hidroxiklorokin - 'Bull's eye' maculopathia}

A malária terápiájaként is alkalmazott aminokinolinok csoportjába tartozó klorokint és hidroxiklorokint a szisztémás lupus erythematosus (SLE), a rheumatoid arthritis (RA) és más, autoimmun kötőszöveti betegségek kezelésében használják. Szemészeti toxikus hatásuk megnyilvánulhat vortex keratopathia, akkomodációs zavarok, valamint retinopathia kialakulásában. A retinopathia prevalenciája 5 éves gyógyszerszedési időtartamot követően 7,5\%, 20 év után pedig 20-50\% [10]. Az aminokinolinok retinatoxicitásának rizikófaktorai a magasabb napi dózis (klorokin: $250 \mathrm{mg} / \mathrm{nap}<$ vagy $3 \mathrm{mg} / \mathrm{kg} / \mathrm{nap}<$, hidroxiklorokin: $400 \mathrm{mg} /$ nap vagy $6,5 \mathrm{mg} / \mathrm{kg} / \mathrm{nap}<$ ) vagy a kumulatív dózis (klorokin: $460 \mathrm{~g}<$, hidroxiklorokin: $1000 \mathrm{~g}<)$, az 5 évnél hosszabb gyógyszerszedési időtartam, az egyidejűleg fennálló vese- vagy májelégtelenség, a 60 év fölötti életkor, illetve egyéb, a retinát érintő betegség jelenléte. A kedvezőbb mellékhatásprofillal rendelkező hidroxiklorokin hazánkban jelenleg nem érhető el. Az aminokinolinok a retina melaninpigmentjeihez kapcsolódnak, és a retinalis pigmentepitheliumban halmozódnak fel, hosszú ideig tartó degeneratív elváltozásokat és fotoreceptor-veszteséget okozva. A retinopathia eleinte tünetmentes, tünetekkel járó esetben a betegek látóélesség-csökkenésre, centrálislátótér-kiesésre, színlátászavarra, valamint a vonalak görbülésére (metamorphopsia) panaszkodnak. A toxicitás korai jelei nem láthatók, ebben az esetben macula-OCT- és multifokális ERG-vizsgálat elvégzése segíthet a károsodás megítélésében. A retinopathia típusos szemfenéki képére jellemző a kétoldali, ökörszem kinézetű pigmentzavar, más néven 'bull's eye' maculopathia (4. ábra). Ebben a stádiumban már egy elörehaladott, visszafordíthatatlan állapot áll fenn. A kezelés bármilyen szemészeti toxikus jelei esetén a terápia azonnali abbahagyása javasolt, mely azonban a felfüggesztés ellenére további károsodáshoz és irreverzibilis látásromláshoz vezethet. A terápia megkezdésekor egy kiindulási szemészeti vizsgálat elvégzése szükséges, mely a szubjektív szemészeti alapvizsgálaton (látóélesség-felvétel, réslámpás vizsgálat pupillatágításban történő szemfenékvizsgálattal) és a centrálislátótérvizsgálaton kívül olyan objektív vizsgálatokból áll, mint a fundus-autofluoreszcencia, a multifokális ERG és a macula-OCT. Az irányelvek szerint a szubjektív tesztek alapján felmerülő gyanút legalább egy objektív vizsgálattal meg kell erósíteni ahhoz, hogy a klorokin/hidroxiklorokin retinopathia diagnózisát felállíthassuk. A korábban a szűréshez tartozó Amsler-rács, színlátástesztek, Ganzfeld ERG és a szemfenéki fotók elvégzése alacsony szenzitivitásuk miatt eltávolításra kerültek a protokollból [11]. A 'bull's eye' maculopathia jellegzetes OCT-képére parafovealisan a retina külső rétegeinek fokális elvékonyodása jellemző. Mivel a retina subfovealisan elhelyezkedő szerkezete nem érintett, az ezt a centrumot megkímélő parafovealis atrophiát „repülő csészealj”
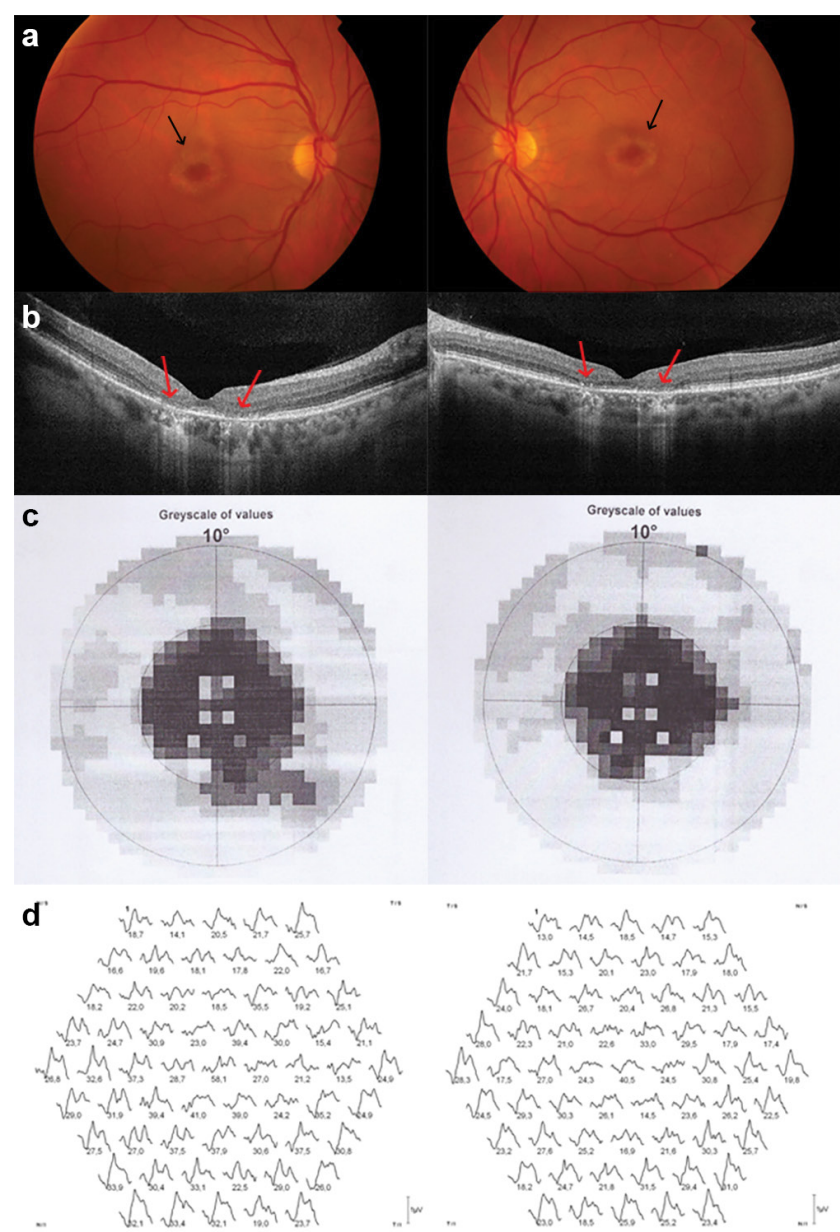

4. ábra

Szisztémás lupus erythematosus miatt Delagil-terápiában része sülő beteg szemfenéki felvételén (a) kétoldali 'bull's eye' maculopathia látható. A macula-OCT-vizsgálaton (b) mindkét olda lon parafovealisan a retina külső rétegeinek fokális elvékonyodása figyelhetô meg (nyilak). Az automata perimetriás (komputeres látótér) felvételen (c) centrális scotoma látható, a multifokális ERG-vizsgálaton (d) centrális túlsúllyal csökkent válaszsưrűségű görbék figyelhetók meg

ERG = elektroretinográfia $;$ OCT $=$ optikaikoherencia-tomográfia 
tünetnek is nevezik az irodalomban. A multifokális ERG a klorokin/hidroxiklorokin retinopathia szürésének legérzékenyebb módszere. A leggyakrabban parafovealisan, késői stádiumban centrálisan is csökkent válaszsưrüségü görbék figyelhetők meg. A szemészeti vizsgálat elvégzése a terápia kezdetét követően félévente javasolt. A szürés a kezdeti vizsgálathoz hasonlóan az alapvizsgálaton kívül centrálislátótér-vizsgálatból és egy objektív vizsgálatból áll. Fontos a betegek tudomására adni, hogy a szemészeti szürés nem előzi meg a retinopathia kialakulását, viszont a károsodás legkorábbi jelei esetén a terápia időben történő felfüggesztése megelőzheti a látásromlás kialakulását vagy további progresszióját.

\section{Tamoxifen - Krisztallinmaculopathia}

Az emlőrák kezelésében a mütétet követően alkalmazott tamoxifen endokrin terápia a gyógyszerszedők 0,9-12\%ában okoz szemészeti elváltozásokat [12]. A gyógyszer hagyományosan alkalmazott alacsony dózisa $(20 \mathrm{mg} /$ nap) mellett ritkább a szemészeti érintettség előfordulása, a toxikus hatás leginkább a magasabb dózisok (120 $\mathrm{mg} / \mathrm{nap}<$ ) esetén jelentkezik, 2-5 évnyi gyógyszerszedést követően [13]. A tamoxifenterápia ajánlott időtartama 5 év, így gondolni kell a felmerülő szemészeti érintettségre. A szemészeti mellékhatások közül a leggyakoribb a krisztallinretinopathia kialakulása. A szemfenéki képen jellemző a kétoldali, maculatájon előforduló, sárgás-fehéres depozitumok megjelenése, ami lehet tünetmentes, társulhat azonban látóélesség-csökkenéssel és színlátászavarral. A retinopathia gyakran járhat maculaoedema kialakulásával. Az optikaikoherencia-tomográfiás (OCT)-vizsgálaton a retina belső rétegeiben elhelyezkedő hiperreflektív depozitumok, esetenként foveolaris cystoid űr és a fotoreceptor-réteg töredezettsége figyelhető meg [14]. A gyógyszernek a retinára kifejtett toxikus hatása dózisfüggő; a legtöbb tanulmány 100 g kumulatív dózis fölött írta le a tamoxifenretinopathia kialakulását, azonban ennél jóval alacsonyabb dózisok esetén is közöltek eseteket az irodalomban [15]. A tamoxifen további lehetséges mellékhatásai között szerepel a szemszárazság, a cornealis depozitumok, a hátsó kérgi cataracta és az opticus neuropathia. A gyógyszer leállítása tünetmentes esetekben nem indokolt, színlátászavar vagy látóélesség-csökkenés fennállásakor azonban a terápia más gyógyszerre történő átváltása vagy annak leállítása javasolt. A tamoxifen szemészeti hatásai reverzibilisek, a kezelés abbahagyását követően a tünetek visszafejlődnek [16]. A betegek szemészeti kontrollvizsgálata 6 havi rendszerességgel ajánlott, látóélesség-, színlátás-, valamint szemfenéki vizsgálat elvégzésével. A spectral-domain-OCT-vel végzett tanulmányok olyan esetekről is beszámoltak, amelyekben az intraretinalis cystoid ürök jelenlétét már tünetmentes, ép szemfenéki kép mellett is megfigyelték. Ennek következtében a tamoxifenretinopathia szûréséhez a felsorolt vizsgálatokon kívül maculaOCT elvégzése is javasolt.

\section{MEK-inhibitorok - MEK-asszociált retinopathia}

A $B R A F$-gén mutációját hordozó melanoma malignum okozta áttétekben szenvedő betegek kezelésében az elmúlt néhány évben teljes paradigmaváltás történt a $M E K$-gátló terápia bevezetésével. A MEK-inhibitorok okozta szemészeti mellékhatások előfordulási valószínüsége közel 90\%, beleértve a tünetmentes eseteket is. A mellékhatások többnyire a retinát érintik, de leírták az uvea és a szemfüggelékek érintettségét is. A MEK-inhibitor-asszociált retinopathiát (MEKAR) a centrális serosus chorioretinopathiához hasonlóan subretinalis folyadékgyülem kialakulása jellemzi, megjelenése azonban bilaterális, multifokális és relatíve szimmetrikus. A MEKAR a leggyakrabban a terápia kezdetét követő első 3 héten belül alakul ki. A látáspanaszok a CSC tüneteihez hasonlóak és a terápia felfüggesztésével reverzibilisek. A gyakori és sokszor tünetmentes mellékhatások miatt a gyógyszer szedése idején az első 3 hónapban havonta történő szemészeti kontrollvizsgálat elvégzése ajánlott. Amennyiben a MEKAR kialakulása nagyfokú látásromlással jár, a MEK-inhibitor-terápia csökkentése vagy felfüggesztése javasolt. A panaszok visszafejlődésével a gyógyszer szoros obszerváció mellett újra adható [17].

\section{Interferonok - Ischaemiás retinopathia}

A daganatellenes, antivirális és immunmoduláns interferon (IFN)-terápiában részesülő betegek 19-64\%-ában alakul ki ischaemiás retinopathia [18]. A retinopathia a leggyakrabban a terápia kezdetét követő 8-12. héten alakul ki, de már 2-6 hét után is közöltek eseteket [19]. A szemészeti érintettség előfordulása összefüggést mutat az IFN kezdő dózisával. A betegség patogenezise nem teljesen tisztázott, a retinalis ischaemia feltehetően immunkomplexeknek a retina ereiben lévő lerakódása, leukocytainfiltráció és ennek következtében a retinalis kapillárisok elzáródása miatt jön létre. Az IFN-retinopathia kialakulása diabeteses és hypertoniás betegeknél gyakoribb, ami a fennálló retinalis kisérkárosodással magyarázható. A klinikai képre jellemzőek a kapilláris keringésből kiesett területek, gyapottépés- (cotton-wool) gócok és retinalis vérzések kialakulása, rendszerint a látóidegfó körül és a hátsó póluson. Az esetek 26-55\%-ában kétoldali érintettség áll fenn [20]. A retinopathia általában tünetmentes és átmeneti; a terápia folytatása ellenére a szemfenéki jelek 4-8 hét után visszafejlődnek, így nem mindig kerül diagnózisra [21]. Súlyos látásromlást okozó szövődmények a legtöbbször olyan betegeknél alakulnak ki, akiknél már az IFN bevezetése előtt más okból fennálló retinopathia volt jelen. Érújdonképződéssel és maculaoedemával járó esetekben anti-VEGF-injekció és panretinalis lézerkezelés elvégzése jön szóba. Az IFNterápia hatására a retinopathián kívül nonarteritises elülső ischaemiás opticus neuropathia is kialakulhat, mely 67\%-ban kétoldali, és a retinopathiához hasonló pato- 
mechanizmussal jön létre, a látóideget ellátó hátsó ciliaris artériák érintettségével [22]. A terápia kezdete előtti szemészeti vizsgálatot követően a betegek 3 havonta történő követése szükséges [3]. A kezelés felfüggesztése csak súlyos, látásromlással is járó retinopathia esetén indokolt.

\section{Antituberkulotikumok - Opticus neuropathia}

A tuberkulózis kezelése több antituberkulotikum együttes adásával történik. A négy első vonalbeli terápia (etambutol, izoniazid, rifampicin, pirazinamid) közül az etambutol és az izoniazid szemészeti toxikus hatása jól ismert. Az etambutol leggyakoribb mellékhatása a látóideg gyulladása (opticus neuritis), mely jellemzően a retrobulbaris szakaszt érinti. A toxicitás dózisdependens: két hónapos gyógyszerszedési időtartamot követően $35 \mathrm{mg} / \mathrm{kg} / \mathrm{nap}$ nál magasabb dózis esetén $18 \%, 25 \mathrm{mg} / \mathrm{kg} /$ nap esetén 5-6\%, míg $15 \mathrm{mg} / \mathrm{kg} /$ nap etambutolt szedő betegeknél kevesebb mint $1 \%$ az incidencia [23]. A klinikai képre jellemző a kétoldali, fokozatosan kialakuló látásromlás, a centrális scotoma és a dyschromatopsia. A tünetek a leggyakrabban a terápia kezdetét követő 4 . és 12 . hónap között jelentkeznek; vesebetegség esetén hamarabb jelenhetnek meg a gyógyszer csökkent kiválasztása és magasabb szérumszintje miatt. Opticus neuropathia megjelenésekor a terápia felfüggesztése javasolt, melyet követően a tünetek általában visszafejlődnek, ez azonban akár heteket-hónapokat is igénybe vehet. Egyes tanulmányok a terápia abbahagyását követően is további látásromlásról számoltak be, amit fóleg az idősebb korosztályban figyeltek meg [24]. Az izoniazid az etambutolhoz hasonlóan opticus neuropathiát okozhat, a két gyógyszer okozta kórkép elkülönítése nagy kihívást jelent. Az izoniazid kiváltotta mellékhatások jóval ritkábbak, kevésbé súlyosak, és a terápia elhagyását követően a tünetek rövid időn belül visszafejlődnek. Amennyiben az etambutol felfüggesztése után a tünetek 6 héten belül nem regrediálnak, az izoniazid abbahagyása egyaránt javasolt [25]. Az antituberkulotikus terápia megkezdése előtt kiindulási szemészeti vizsgálat elvégzése szükséges, látóélesség-, kontrasztérzékenység-, színlátás- és szemfenéki vizsgálattal. A szemészeti kontroll a $15 \mathrm{mg} / \mathrm{kg} /$ nap dózist meghaladó etambutolterápia és a rizikófaktorok fennállása esetén havonta, egyéb esetekben 3 havonta javasolt. Mivel az opticus neuropathia a betegség korai szakaszában tünetmentes, az említett vizsgálatokon kívül látótérvizsgálat és papilla-OCT elvégzése egyaránt szükséges a retinalis idegrost-károsodás szürésére [26].

\section{Foszfodiészteráz-gátlók - Átmeneti látászavar és NA-EION}

A foszfodiészteráz-5 (PDE-5)-gátló hatóanyagok széles körben alkalmazott gyógyszerek a merevedési zavarok kezelésére. A leggyakrabban szedett gyógyszerek a szil- denafil és a tadalafil. A szildenafil ajánlott dózisa 25-50 mg, mely legfeljebb 100 mg-ig emelhető naponta. A gyógyszer hatására jelentkező legjellemzőbb szemészeti tünetek között szerepel a színlátászavar (kékes árnyalatban történő látás vagy cyanopsia) és a fényre való fokozott érzékenység (photophobia). A tünetek a leggyakrabban a gyógyszer bevételét követő 1-2 órában jelentkeznek, majd 3-4 órával később visszafejlődnek [27]. A szildenafil hatására kialakuló átmeneti látászavar maradandó látáskárosodással nem jár. A tünetek előfordulása dózisfüggő, 25-100 mg esetén a betegek 3-11\%ában, $200 \mathrm{mg}$ dózis szedésekor 50\%-ban, 600 mg esetén 100\%-ban jelentkeznek szemészeti panaszok [28]. A PDE-5-gátló terápiát követő nonarteritises elülső ischaemiás opticus neuropathia (NA-EION) kialakulása feltehetően a gyógyszer hatására bekövetkező fiziológiás éjszakai hypotensio fokozódása és a látóidegfó ischaemiája következtében jön létre. Az esetek többségében ébredéskor jelentkezik a látásromlás. Az irodalomban a szildenafil bevétele után 6-36 órával közölték a tünetek megjelenését. A NA-EION bekövetkezésének nagyobb a valószínúsége olyan PDE-5-gátló-szedőknél, akik a kórkép egyéb rizikófaktoraival (diabetes, hypertonia, hypercholesterinaemia) rendelkeznek [29]. A PDE-5gátlók alkalmazása során jelentkező szemészeti panaszok, illetve korábban lezajlott NA-EION esetén a gyógyszer használata nem javasolt.

\section{Orális antikoncipiensek - Szemfenéki érelzáródás}

Az ösztrogén- és progeszterontartalmú orális antikoncipienseket a leggyakrabban fogamzásgátlás céljából, de menorrhagia, endometriosis és premenstruációs szindróma esetén is alkalmazzák. Szemészeti mellékhatásaik között szerepel a szemszárazság és a kontaktlencse-viselési intolerancia, valamint súlyosabb esetben látást veszélyeztető neuroophthalmologiai és vascularis kórképekkel is társulhatnak. A neuroophthalmologiai betegségek közül pseudotumor cerebri és neuritis retrobulbaris kialakulásáról közöltek eseteket [30]. A fogamzásgátlókat szedők thromboemboliás eseményekre való kockázata közel háromszoros a normálpopulációhoz viszonyítva [31]. Artériás és vénás szemfenéki érelzáródás egyaránt előfordulhat, melynek hátterében a retinalis erekben bekövetkező thrombosis áll. A szemészeti kórképek közül a retina vérkeringési zavarai állnak a leginkább összefüggésben a szájon át szedett fogamzásgátlók használatával (5. ábra). Az elzáródás következtében a retina ischaemiás károsodása alakul ki, a vascularis endothelialis növekedési faktor (VEGF) termelődése fokozódik, ami az elülső és a hátulsó szegmentumban kialakuló érújdonképződéseket és az emelkedett kapilláris permeabilitás következtében maculaoedemát okoz. Magasabb thrombosisrizikójú nők esetében javasolt a kombinált orális antikoncipiensek helyett harmadik generációs, progeszterontartalmú fogamzásgátlók használata. 


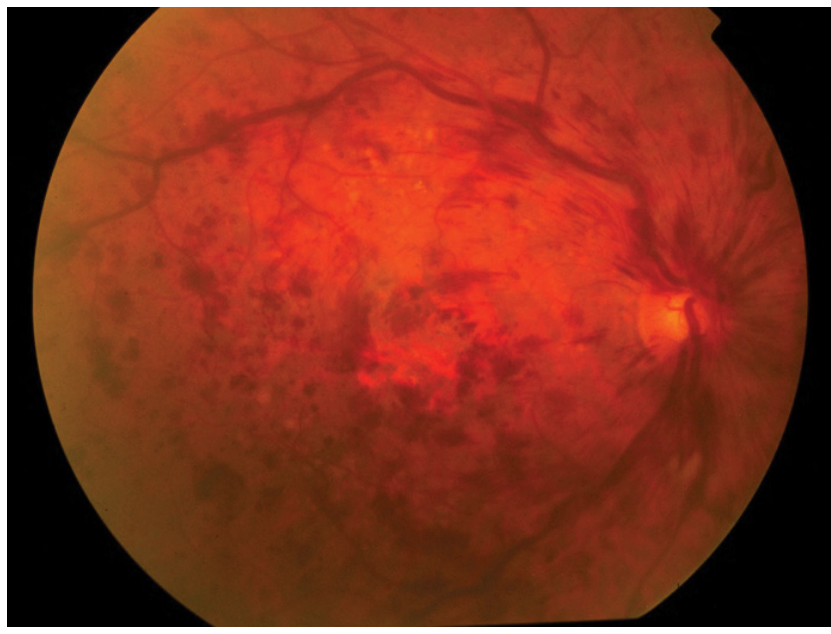

5. ábra

Jobb oldali szemfenéki vénás törzselzáródás klinikai képe A szemfenéki fotón fundusszerte csíkolt és tócsás vérzések, valamint telt, kanyargós vénák láthatók

\section{Antiepileptikumok - Myopiás shift és zárt zugú glaucoma}

A topiramátot az epilepszián kívül a migrén profilaktikus kezelésében is alkalmazzák. Szemészeti mellékhatása a fénytörésnek a rövidlátás (myopia) irányába történő eltolódása, ami a terápia kezdetét követően néhány nap alatt kialakuló homályos látásban nyilvánulhat meg. Súlyosabb esetben a topiramát hatására akut kétoldali szekunder zárt zugú glaucoma alakulhat ki. A szemnyomásemelkedés jellemzően a terápia bevezetését követő első két hétben jelentkezik [32]. Kialakulása független a gyógyszer dózisától, $50 \mathrm{mg}$ és több mint $100 \mathrm{mg}$ esetén is számoltak be esetekról. A glaucomás roham tüneteihez hasonlóan a betegek panaszai a fej- és szem körüli fájdalom, hányinger, homályos látás és szemvörösség. A topiramát szedése alatt tünetmentes esetekben nem szükséges rutinszerú szűrôvizsgálat elvégzése, azonban fel kell hívni a beteg figyelmét, hogy látásromlás vagy szemfájdalom esetén mihamarabb keresse fel szemorvosát [33].

A vigabatrin szedése kétoldali, nazális dominanciájú, koncentrikus látótérszúkületet okozhat. A tünetek a betegek 30-40\%-ában fordulhatnak elö, fél-két évig tartó terápiát követóen [34]. A betegek sokáig panaszmentesek, és nem veszik észre a látásromlást, egészen addig, ameddig a károsodás a centrális látóterüket nem érinti. A tünetek bármilyen látható szemfenéki elváltozás nélkül megjelenhetnek, idővel azonban papillaatrophia is kialakulhat. A terápia kezdete előtt javasolt szemészeti ellenőrzés látótér- és szemfenéki vizsgálat elvégzésével. Gyermekeknél a megfelelő kooperáció hiányában VEP-vizsgálat elvégzése javasolt. Ezt követően a terápia időtartama alatt 3 havonta, majd a gyógyszer abbahagyása után a 3. és a 6. hónapban javasolt a szưrővizsgálat. Korábbi tanulmányok eredménye szerint a panaszok nem fejlődnek vissza a gyógyszer abbahagyásával, a további progresszió azonban elkerülhető [35].

\section{Antidepresszánsok - Szemszárazság és akkomodációs zavarok}

A depresszió az egyik leggyakoribb pszichiátriai tünetegyüttes, mely a fiatal és az idős korosztályt egyaránt érintheti [36]. A legszélesebb körben alkalmazott antidepresszánsok a szelektív szerotoninvisszavétel-gátlók (selective serotonin reuptake inhibitors - SSRI-k). Az emelkedett szerotoninszint a cornea szenzitivitását és a könnyreflexet csökkenti, így száraz szem kialakulásához vezet [37]. Egy másik gyógyszercsoport, a triciklikus antidepresszánsok (tricyclic antidepressants - TCA) antikolinerg hatásuk következtében a csökkent könnytermelésen kívül a sugárizom bénításával (cycloplegia) akkomodációs zavarokat és közelre nézéskor jelentkező fókuszálási nehezítettséget okozhatnak. A pupilla szúkítéséért felelős izom elernyesztésével a pupillák tágulását (mydriasis) idézik elő, mely az arra hajlamos egyéneknél pupillaris blokk kialakulására és akut glaucomás rohamra prediszponálhat. Az SSRI-k kismértékü antikolinerg és adrenerg hatásuk révén szintén hajlamosíthatnak akut zárt zugú glaucoma kialakulására, de ritkábban, mint a TCA-k esetében. Amennyiben a beteg 40 éves elmúlt, és hypermetropiás, vagy a családjában elófordult glaucoma, az antidepresszáns felírása előtt szemészeti vizsgálat elvégzése javasolt a kockázat megítélésére [38]. Az utóbbi években a szertralin okozta maculopathiát több eset kapcsán is leírták, melynek klinikai képe megegyezik a klorokin és hidroxiklorokin asszociálta 'bull's eye' maculopathia szemfenéki tüneteivel. A terápia felfüggesztésével a szemfenéki jelek visszafejlődése ellenére a látáspanaszokban nem figyeltek meg javulást.

$\mathrm{Az}$ antidepresszánsok mellett szemszárazságot okozhatnak az allergiaellenes antihisztaminok, valamint a vérnyomáscsökkentő béta-blokkolók és diuretikumok.

\section{Izotretinoin - Meibom-mirigy-diszfunkció, szemszárazság és éjszakai vakság}

Az izotretinoin a súlyos acne kezelésében alkalmazott terápia. Leggyakoribb szemészeti mellékhatásai a blepharoconjunctivitis, a szemszárazság és a visszatérő árpák kialakulása. A szemfelszín károsodásából adódóan a beteg további panaszai a homályos látás, a fényérzékenység és a kontaktlencse-viselési intolerancia. A tünetek megjelenését általában a terápia kezdetét követő 4 . hónapban figyelték meg [39]. A szemészeti panaszok hátterében a szemhéjakban elhelyezkedő Meibom-mirigyek múködési zavara áll. A Meibom-mirigyek lipidszekrétuma alkotja a könnyfilm legkülső rétegét, mely stabilizálja a könnyfilmet. Az izotretinoin hatására a bőr faggyútermeléséhez hasonlóan csökken a mirigyek szekrétumának termelése, a könnyfilm ezáltal instabillá válik, és a könny elpárolog. Ennek következtében az elégséges könnymennyiség ellenére a könny minőségi zavara miatt szemszárazság alakul ki, és a szemfelszín károsodik. Az izotretinoin és metabolitjainak szemfelszínt irritáló hatása tovább súlyosbít- 
hatja a beteg panaszait. A tünetek reverzibilisek, a kezelés felfüggesztését követően a szemészeti panaszok egy hónapon belül visszafejlődnek. A gyógyszer felírásakor a beteget figyelmeztetni kell a gyakori szemszárazságos panaszok kialakulására, és múkönny használatát kell tanácsolni. Amennyiben ennek ellenére a panaszok fennállnak, az izotretinoin dózisának csökkentése vagy abbahagyása javasolt.

Az izotretinoin további, potenciálisan veszélyes mellékhatása az éjszakai vakság (nyctalopia) kialakulása, mely a sötétben történő vezetést rendkívül kockázatossá teheti. Előfordulása az izotretinoint szedők körében 4-6\%-ra becsülhető. A tünetek általában a gyógyszer szedését követő első két héten belül jelentkeznek [40]. A betegek gyakori panasza a homályos látás, a fényérzékenység (photophobia), a káprázásos panaszok és a csökkent éjszakai látás, amit jellemzően vezetés közben vagy a fények hirtelen lekapcsolását követően vesznek észre. Az elektrofiziológiai vizsgálatokon tartós, csökkent scotopicus válaszokat és a sötétadaptáció romlását figyelték meg. Az izotretinoin kiváltotta nyctalopia egyetlen ismert rizikótényezője az alacsony A-vitamin-szint, ebben az esetben a gyógyszer abbahagyásán kívül az A-vitamin pótlása javasolt. A terápia felfüggesztésével a szemészeti érintettség reverzibilitásáról megoszlanak a vélemények. Egyes tanulmányok a tünetek visszafejlődését írták le, míg mások az abbahagyást követően évekkel később is a sötétben jelentkező látási nehezítettségről és az elektrofiziológiai vizsgálatokon megfigyelhető eltérésekről számoltak be [41].

A pseudotumor cerebri (PTC), vagy más néven idiopathiás intracranialis hypertensio, ismeretlen eredetú koponyaüri nyomásfokozódás, melynek hátterében intracranialis térfoglalás nem igazolható. Jellemzően fiatal, túlsúlyos nóket érint. Tünetei a koponyaưri nyomásfokozódásból adódnak: fejfájás, hányinger, hányás, homályos látás, kettős látás, fülzúgás és tarkókötöttség jellemzi. Az idiopathiás eseteken kívül előfordulhat gyógyszerasszociált PTC is, melyet a leggyakrabban növekedésihormon-terápiával, izotretinoin, tetraciklinek és orális antikoncipiensek szedésével, valamint a hosszú távú szteroidterápia megvonásával hoztak összefüggésbe. A tünetek általában az izotretinointerápia kezdetét követően 2 hónappal jelentkeznek, és a kezelés felfüggesztésével teljes mértékben visszafejlődnek. Az anamnézisben szereplő PTC az izotretinoin szedésének nem ellenjavallata, a terápia szoros, havonta történő szemészeti kontroll elvégzése mellett alkalmazható [42].

\section{Alfa-receptor-blokkolók - Intraoperatív 'floppy' iris szindróma}

Az alfa-1A-receptor-blokkoló tamszulozin a jóindulatú prosztatamegnagyobbodás (benign prostatic hyperplasia - BPH) tüneteinek enyhítésére használt gyógyszer. A vizeletürítési zavarok (lower urinary tract syndrome LUTS) a 70-79 éves férfiak 46\%-át érintik, leggyakoribb okuk a BPH [43]. Ugyanerre a korosztályra jellemző az időskori szürkehályog kialakulása. Az alfa-1-receptorok a prosztatán kívül jelen vannak az iris pupilla tágításáért felelős, szimpatikus beidegzésú, sugárirányú izomrostjaiban is, melyek gátlásával az izom tónusa csökken, a pupilla szúlkítését végző paraszimpatikus beidegzés túlsúlyba kerül, és a pupilla beszúkül. Az intraoperatív 'floppy' iris szindróma (IFIS) klinikai jellemzői a mútét során a tónusát vesztett, petyhüdt iris folyadékáramlás hatására fellépő lebegése, a mütéti sebekbe történő elöreesése, valamint a mütét közben a pupillatágítók alkalmazása ellenére bekövetkező progresszív pupillaszúküulet. Mindezek következtében fokozódik a mưtéti szövődmények kialakulásának kockázata, mint például az iris traumás károsodása vagy a hátsó lencsetok szakadása. Az IFIS előfordulási gyakorisága a szürkehályog-mütétek esetén 0,8-12,6\% [44]. Az alfa-1A-receptort a tamszulozin szelektíven gátolja, míg a terazozin, az alfuzozin és a doxazozin változó affinitással, nem szelektíven kötődik az alfa-1-receptor-család további altípusaihoz is, ezért az általuk okozta IFIS előfordulása ritkább, s tünetei kevésbé súlyosak [45]. A kórkép megjelenésére a nők esetében is gondolni kell, akik az alfa-receptor-blokkolókat hypertonia, vesekólika, valamint vizeletürítési nehezítettség miatt szedhetik. A tamszulozin szürkehályog-mútét előtti felfüggesztéséről megoszlanak a vélemények, mivel a terápia abbahagyása után évekkel később is kialakulhat IFIS [46].

\section{Thrombocytaaggregáció-gátló és antikoaguláns gyógyszerek}

A thrombocytaaggregáció-gátló és az antikoaguláns terápia alkalmazása - különösen kombinációban történő használatuk esetén - a mütétek során fokozott vérzésveszéllyel jár. A vérzés kockázata függ a beavatkozás típusától: a retrobulbaris érzéstelenítés, a cataractamütét és az intravitrealis injekciók alacsony vérzéskockázatú beavatkozások, a vitreoretinalis mútétek esetén a rizikó vitatott, míg a trabeculectomia, az orbitamútétek és a dacryocystorhynostomia fokozott vérzésveszéllyel járnak. A fokozott vérzéskockázat a beavatkozástól függően megnyilvánulhat subconjunctivalis vérzésben, valamint látást veszélyeztető szövődmények kialakulásában is, mint a retrobulbaris haematoma és az expulzív chorioideavérzés [47]. A mütét tervezésekor a beteg thrombocytaaggregáció-gátló/antikoaguláns terápiájának leállítása a thromboemboliás kockázatok mérlegelésével, a beteg kardiológusával egyeztetve, körültekintően ajánlott. A mútéti kockázatokon kívül a nedves típusú maculadegeneratiós betegek spontán érhártyabevérzésének előfordulása is magasabb antikoaguláns terápia mellett.

\section{Következtetés}

A szisztémás gyógyszerek okozta szemészeti mellékhatások rendkívül változatosak lehetnek, mind a tüneteket, mind az elváltozások prognózisát tekintve (1. táblázat). 
1. táblázat |A szisztémás gyógyszerek szemészeti mellékhatásai

\begin{tabular}{|c|c|c|c|}
\hline Gyógyszercsoport & Hatóanyag & Indikáció & Szemészeti mellékhatás \\
\hline Antiarrhythmiás gyógyszerek & Amiodaron & Arrhythmia & $\begin{array}{l}\text { Cornea verticillata* } \\
\text { Opticus neuropathia }\end{array}$ \\
\hline Gyulladáscsökkentők & Metilprednizolon & $\begin{array}{l}\text { Autoimmun betegségek } \\
\text { Hátsó uveitisek } \\
\text { A-EION }\end{array}$ & $\begin{array}{l}\text { Szteroid indukálta glaucoma } \\
\text { Hátsó kérgi cataracta } \\
\text { Centrális serosus chorioretinopathia* }\end{array}$ \\
\hline Aminokinolinok & Klorokuin & $\begin{array}{l}\text { Autoimmun betegségek } \\
\text { Maláriaprofilaxis }\end{array}$ & 'Bull's eye' maculopathia \\
\hline \multirow[t]{3}{*}{ Daganatellenes gyógyszerek } & Interferon-alfa- $2 b$ & $\begin{array}{l}\text { Hepatitis C-vírus } \\
\text { Melanoma malignum } \\
\text { Myeloma multiplex } \\
\text { Krónikus myeloid leukaemia }\end{array}$ & Ischaemiás retinopathia* \\
\hline & Tamoxifen & Emlőrák & Krisztallinretinopathia* \\
\hline & $\begin{array}{l}\text { MEK-inhibitorok } \\
\text { Trametinib } \\
\text { Kobimetinib } \\
\text { Binimetinib }\end{array}$ & Melanoma malignum & MEK-asszociált retinopathia* \\
\hline Antituberkulotikumok & $\begin{array}{l}\text { Etambutol } \\
\text { Izoniazid }\end{array}$ & $\mathrm{Tbc}$ & Opticus neuropathia \\
\hline PDE-5-gátlók & $\begin{array}{l}\text { Szildenafil } \\
\text { Tadalafil } \\
\text { Vardenafil }\end{array}$ & Erektilis funkciózavarok & $\begin{array}{l}\text { Átmeneti látászavarok* } \\
\text { (cyanopsia, photophobia) } \\
\text { NA-EION }\end{array}$ \\
\hline Orális antikoncipiensek & Ösztrogén-gesztagén & $\begin{array}{l}\text { Fogamzásgátlás } \\
\text { Menorrhagia } \\
\text { Premenstruális szindróma } \\
\text { Endometriosis }\end{array}$ & $\begin{array}{l}\text { Szemszárazság* } \\
\text { Pseudotumor cerebri* } \\
\text { Szemfenéki keringészavarok }\end{array}$ \\
\hline \multirow[t]{2}{*}{ Antiepileptikumok } & Topiramát & $\begin{array}{l}\text { Migrénprofilaxis } \\
\text { Epilepszia }\end{array}$ & $\begin{array}{l}\text { Myopiás shift* } \\
\text { Kétoldali glaucomás roham }\end{array}$ \\
\hline & Vigabatrin & Epilepszia & Kétoldali koncentrikus látótérszúküulet \\
\hline Antidepresszánsok & $\begin{array}{l}\text { SSRI } \\
\text { Citaloprám, eszcitaloprám, } \\
\text { fluoxetin, fluvoxamin, paroxetin, } \\
\text { szertralin } \\
\text { TCA } \\
\text { Amitriptilin, klomipramin, } \\
\text { imipramin, maprotilin, mianszerin }\end{array}$ & $\begin{array}{l}\text { Depresszió } \\
\text { Szorongásos zavarok } \\
\text { Étkezési zavarok }\end{array}$ & $\begin{array}{l}\text { Szemszárazság* } \\
\text { Akkomodációs zavarok* } \\
\text { Akut glaucomás roham }\end{array}$ \\
\hline A-vitamin-analóg & Izotretinoin & Acne vulgaris & $\begin{array}{l}\text { Meibom-mirigy-diszfunkció* } \\
\text { (blepharitis, szemszárazság) } \\
\text { Nyctalopia } \\
\text { Pseudotumor cerebri* }\end{array}$ \\
\hline Alfa-1-receptor-gátlók & $\begin{array}{l}\text { Tamszulozin } \\
\text { Alfuzozin } \\
\text { Terazozin } \\
\text { Doxazozin }\end{array}$ & Benignus prostata hyperplasia & Intraoperatív 'floppy' iris szindróma \\
\hline $\begin{array}{l}\text { Thrombocytaaggregáció-gátlók } \\
\text { és antikoagulánsok }\end{array}$ & $\begin{array}{l}\text { Acetilszalicilsav } \\
\text { Klopidogrél } \\
\text { Tiklopidin } \\
\text { Acenokumarol } \\
\text { Warfarin } \\
\text { Rivaroxaban } \\
\text { Dabigatrán } \\
\text { Apixaban }\end{array}$ & $\begin{array}{l}\text { Vénás thrombosis prevenciója } \\
\text { Pitvarfibrilláció } \\
\text { Múbillentyú }\end{array}$ & $\begin{array}{l}\text { Subconjunctivalis vérzés* } \\
\text { Üvegtesti vérzés* } \\
\text { Retrobulbaris haematoma* } \\
\text { Chorioideavérzés* }\end{array}$ \\
\hline
\end{tabular}

*A terápia felfüggesztésével a tünetek visszafordíthatók.

A-EION = arteritises elülső ischaemiás opticus neuropathia; MEK = mitogénaktivált proteinkináz; NA-EION = nonarteritises elülső ischaemiás opticus neuropathia; PDE-5 = foszfodiészteráz-5; SSRI = szelektív szerotoninvisszavétel-gátló; Tbc = tuberkulózis; TCA = triciklusos antidepreszszáns 
A gyógyszerek okozhatnak reverzibilis és irreverzibilis látásromlást, valamint egyéb szemészeti panaszokat, melyek a gyógyszerszedés befejezésével javulhatnak vagy meg is szűnhetnek. A közleményben tárgyalt gyógyszereket felíró, társszakmabeli orvosoknak fontos ismerniük a terápia lehetséges szemészeti mellékhatásait, hogy a betegeket az ajánlásoknak megfelelő rendszerességgel szemészeti vizsgálatra küldjék. A gyógyszerek toxikus hatásainak korai felismerésével az esetek nagy részében a tünetek visszafordíthatók, a további progresszió és a maradandó látáskárosodás megelőzhetô.

Anyagi támogatás: A közlemény megírása, illetve a kapcsolódó kutatómunka anyagi támogatásban nem részesült.

Szerzői munkamegosztás: A vizsgálat tervezése: C. C. K. I., N. Z. Zs. A vizsgálatok elvégzése: C. C., S. G., H. H., Sz. Zs. A közlemény megírása: C. C., K. I. A közlemény kritikai revíziója: S. G., H. H., Sz. Zs., N. Z. Zs., K. I. A cikk végleges változatát valamennyi szerző elolvasta és jóváhagyta.

Érdekeltségek: A szerzőknek nincsenek érdekeltségeik.

\section{Irodalom}

[1] Mäntyjärvi M, Tuppurainen K, Ikäheimo K. Ocular side effects of amiodarone. Surv Ophthalmol. 1998; 42: 360-366.

[2] Mindel JS, Anderson J, Johnson G, et al. Absence of bilateral vision loss from amiodarone: a randomized trial. Am Heart J. 2007; 153: 837-842.

[3] Gurwood AS. Optometric clinical practice recommendations for monitoring ocular toxicity of selected medications. American Optometric Association. Available from: www.aoa.org/Documents/optometrists/QI/optometric-clinical-practice-recommendations-for-monitoring-ocular-toxicity-of-selected-medications.pdf [accessed: May 13, 2015].

[4] Godel V, Feiler-Ofry V, Stein R. Systemic steroids and ocular fluid dynamics. I. Analysis of the sample as a whole: Influence of dosage and duration of therapy. II. Systemic versus topical steroids. Acta Ophthalmol (Copenh). 1972; 50: 655-663, 664676.

[5] James ER. The etiology of steroid cataract. J Ocul Pharmacol Ther. 2007; 23: 403-420.

[6] Peponis V, Kyttaris VC, Chalkiadakis SE, et al. Ocular side effects of anti-rheumatic medications: what a rheumatologist should know. Lupus 2010; 19: 675-682.

[7] Csorba A, Soproni A, Maneschg O, et al. Application of corticosteroid eye drops for allergic eye diseases in children. [A kortikoszteroidtartalmú szemcseppek alkalmazása gyermekkori allergiás szembetegségek kezelésében.] Orv Hetil. 2019; 160: 329-337. [Hungarian]

[8] Daruich A, Matet A, Dirani A. Central serous chorioretinopathy: recent findings and new physiopathology hypothesis. Prog Retin Eye Res. 2015; 48: 82-118.

[9] Han JM, Hwang JM, Kim JS, et al. Changes in choroidal thickness after systemic administration of high-dose corticosteroids: a pilot study. Invest Ophthalmol Vis Sci. 2014; 55 : 440-445.

[10] Melles RB, Marmor MF. The risk of toxic retinopathy in patients on long-term hydroxychloroquine therapy. JAMA Ophthalmol. 2014; 132: 1453-1460.
[11] Marmor MF, Kellner U, Lai TY, et al. Recommendations on screening for chloroquine and hydroxychloroquine retinopathy (2016 Revision). Ophthalmology 2016; 123: 1386-1394.

[12] Alwitry A, Gardner I. Tamoxifen maculopathy. Arch Ophthalmol. 2002; 120: 1402 .

[13] Bourla DH, Sarraf D, Schwartz SD. Peripheral retinopathy and maculopathy in high-dose tamoxifen therapy. Am J Ophthalmol. 2007; 144: 126-128.

[14] Gualino V, Cohen SY, Delyfer MN, et al. Optical coherence tomography findings in tamoxifen retinopathy. Am J Ophthalmol. 2005; 140: 757-758.

[15] Vinding T, Nielsen NV. Retinopathy caused by treatment with tamoxifen in low dosage. Acta Ophthalmol (Copenh). 1983; 61: 45-50.

[16] Besch D, Zrenner E, Sadowski B. Reversibility of Tamoxifen ${ }^{\circledR}$ retinopathy - a ten-year follow-up. Neuro-Ophthalmology 2009; 32: 214-221.

[17] Méndez-Martínez S, Calvo P, Ruiz-Moreno O, et al. Ocular adverse events associated with MEK inhibitors. Retina 2019; 39: $1435-1450$.

[18] Schulman JA, Liang C, Kooragayala LM, et al. Posterior segment complications in patients with hepatitis $\mathrm{C}$ treated with interferon and ribavirin. Ophthalmology 2003; 110: 437-442.

[19] Okuse C, Yotsuyanagi H, Nagase Y, et al. Risk factors for retinopathy associated with interferon $\alpha-2 b$ and ribavirin combination therapy in patients with chronic hepatitis C. World J Gastroenterol. 2006; 12: 3756-3759.

[20] Medhat E, Esmat G, Hamza E, et al. Ophthalmological side effects of interferon therapy of chronic hepatitis C. Hepatobiliary Surg Nutr. 2016; 5: 209-216.

[21] Abd El-Badie Mohamed M, Abd-El Azeem Eed K. Retinopathy associated with interferon therapy in patients with hepatitis $\mathrm{C}$ virus. Clin Ophthalmol. 2012; 6: 1341-1345.

[22] Fraunfelder FW, Fraunfelder FT. Interferon alfa-associated anterior ischemic optic neuropathy. Ophthalmology 2011; 118: 408-411.e2.

[23] Koul PA. Ocular toxicity with ethambutol therapy: timely recaution. Lung India 2015; 32: 1-3.

[24] Chai SJ, Foroozan R. Decreased retinal nerve fibre layer thickness detected by optical coherence tomography in patients with ethambutol-induced optic neuropathy. Br J Ophthalmol. 2007; 91: 895-897.

[25] Chan RY, Kwok AK. Ocular toxicity of ethambutol. Hong Kong Med J. 2006; 12: 56-60

[26] Gümüş A, Öner V. Follow up of retinal nerve fiber layer thickness with optic coherence tomography in patients receiving antitubercular treatment may reveal early optic neuropathy. Cutan Ocul Toxicol. 2015; 34: 212-216.

[27] Diederen RM, La Heij EC, Markerink-van Ittersum M, et al. Selective blockade of phosphodiesterase types 2, 5 and 9 results in cyclic 3'5' guanosine monophosphate accumulation in retinal pigment epithelium cells. Br J Ophthalmol. 2007; 91: 379-384.

[28] Goldstein I, Lue TF, Padma-Nathan H, et al. Oral sildenafil in the treatment of erectile dysfunction. Sildenafil Study Group. N Engl J Med. 1998; 338: 1397-1404.

[29] McGwin G Jr, Vaphiades MS, Hall TA, et al. Non-arteritic anterior ischaemic optic neuropathy and the treatment of erectile dysfunction. Br J Ophthalmol. 2006; 90: 154-157. [This article has been retracted. Retraction: Br J Ophthalmol. 2011; 95(4): 595.]

[30] Malek N, Lebuisson DA. Adverse ocular reactions to oral contraceptive use. [Le point sur les complications oculaires de la contraception orale.] Contracept Fertil Sex (Paris) 1992; 20: 441444. [French]

[31] Peragallo Urrutia R, Coeytaux RR, et al. Risk of acute thromboembolic events with oral contraceptive use: a systematic review and meta-analysis. Obstet Gynecol. 2013; 122: 380-389. 
[32] Fraunfelder FW, Fraunfelder FT, Keates EU. Topiramate-associated acute, bilateral, secondary angle-closure glaucoma. Ophthalmology 2004; 111: 109-111.

[33] P. Watts. Ocular side effects of topiramate - frequently asked questions. The Royal College of Ophthalmologists, Paediatric Sub-Committee, London, 2010. Available from: https://www. rcophth.ac.uk/wp-content/uploads/2014/12/2010_PROF_ 124_FAQ-Topiramate.pdf [accessed: January 6, 2020].

[34] Krauss GL. Evaluating risk for vigabatrin treatment. Epilepsy Curr. 2009; 9: 125-129.

[35] Hardus P, Verduin WM, Postma G, et al. Long term changes in the visual fields of patients with temporal lobe epilepsy using vigabatrin. Br J Ophthalmol. 2000; 84: 788-790.

[36] Torzsa P, Szeifert L, Dunai K, et al. Diagnosis and therapy of depression in primary care. [A depresszió diagnosztikája és kezelése a családorvosi gyakorlatban.] Orv Hetil. 2009; 150: 1684-1693. [Hungarian]

[37] Acan D, Kurtgoz P. Influence of selective serotonin reuptake inhibitors on ocular surface. Clin Exp Optom. 2017; 100: 83-86.

[38] Ah-Kee EY, Egong E, Shafi A, et al. A review of drug-induced acute angle closure glaucoma for non-ophthalmologists. Qatar Med J. 2015; 2015: 6.

[39] Neudorfer M, Goldshtein I, Shamai-Lubovitz O, et al. Ocular adverse effects of systemic treatment with isotretinoin. Arch Dermatol. 2012; 148: 803-808.

[40] Halpagi P, Grigg J, Klistorner A, et al. Night blindness following low-dose isotretinoin. J Eur Acad Dermatol Venereol. 2008; 22: 893-894.
[41] Mollan SP, Woodcock M, Siddiqi R, et al. Does use of isotretinoin rule out a career in flying? Br J Ophthalmol. 2006; 90 : 957-959.

[42] Tintle SJ, Harper JC, Webster GF, et al. Safe use of therapeuticdose oral isotretinoin in patients with a history of pseudotumor cerebri. JAMA Dermatol. 2016; 152: 582-584.

[43] Romics I. Treatment of benign prostate hyperplasia. [A benignus prostatahyperplasia kezelése.] Orv Hetil. 2010; 151: 506-508. [Hungarian]

[44] Kaczmarek IA, Prost ME, Wasyluk J. Clinical risk factors associated with intraoperative floppy iris syndrome: a prospective study. Int Ophthalmol. 2019; 39: 541-549.

[45] Palea S, Chang DF, Rekik M, et al. Comparative effect of alfuzosin and tamsulosin on the contractile response of isolated rabbit prostatic and iris dilator smooth muscles. Possible model for intraoperative floppy-iris syndrome. J Cataract Refract Surg. 2008; 34: 489-496.

[46] Chang DF, Osher RH, Wang L, et al. A prospective multicenter evaluation of cataract surgery in patients taking tamsulosin (Flomax). Ophthalmology 2007; 114: 957-964.

[47] Kiire CA, Mukherjee R, Ruparelia N, et al. Managing antiplatelet and anticoagulant drugs in patients undergoing elective ophthalmic surgery. Br J Ophthalmol. 2014; 98: 1320-1324.

(Czakó Cecília dr., Budapest, Üllői út 26., 1085 e-mail: cecilia.czako@gmail.com

\section{"Nihil peccant oculi, si animus oculis imperat." (Nem vét a szem, ha az ész parancsol neki.)}

A cikk a Creative Commons Attribution 4.0 International License (https://creativecommons.org/licenses/by/4.0/) feltételei szerint publikált Open Access közlemény, melynek szellemében a cikk bármilyen médiumban szabadon felhasználható, megosztható és újraközölhető, feltéve, hogy az eredeti szerző és a közlés helye, illetve a CC License linkje és az esetlegesen végrehajtott módosítások feltüntetésre kerülnek. (SID_1) 